(c) American Dairy Science Association, 2005.

\title{
Proteolysis, Fermentation Efficiency, and In Vitro Ruminal Digestion of Peanut Stover Ensiled with Raw or Heated Corn
}

\author{
C.-M. J. Yang \\ Department of Animal Science, National I-Lan University, I-Lan, Taiwan 26015, Republic of China
}

\begin{abstract}
Peanut stover (PS) is similar to full-bloom alfalfa hay in chemical composition. The objective of this study was to assess the effect of adding raw or heated corn meal to $\mathrm{PS}$ at ensiling on silage $\mathrm{N}$ components, fermentation acids, and digestion by ruminal microorganisms. The PS was collected after harvesting of peanuts and ensiled immediately without and with addition of raw or heated corn meal (100 g/kg of fresh weight). Corn was added to PS so that the initial mixture would contain adequate dry matter (DM) (approximately 30\%) and additional nonfiber carbohydrate to enhance silage fermentation. After $8 \mathrm{wk}$ of silo fermentation, corn-treated silages contained less structural carbohydrates but more nonfiber carbohydrates compared with the untreated control. A shift from hemicellulose to nonfiber carbohydrate use during silage fermentation was evident by corn treatment. Additional corn at ensiling resulted in silage $\mathrm{N}$ with less water-soluble $\mathrm{N}$, protein $\mathrm{N}$, nonprotein $\mathrm{N}$, nonprotein nonammonia $\mathrm{N}$ (peptides plus amino acids), and ammonia N. Based on changes in soluble nonprotein $\mathrm{N}$ before and after ensiling, the amount of proteolysis was approximately $66 \%$ for control silage and was nearly $40 \%$ lower in response to corn treatment. Adding corn increased silage lactic acid, but both acetic and propionic acids decreased. These changes were reflected in the lower $\mathrm{pH}$ and higher fermentation efficiency with corn-treated silages. More DM was digested and greater amounts of volatile fatty acids, except for branched-chain acids, were produced in vitro by ruminal microorganisms with corn-treated silages. In addition, incubations with silage treated with heated corn contained higher concentrations of acetic and propionic acids compared with raw corn. In vitro ammonia accumulation per unit of DM digested was lower for corn treatments than the control, and for heated corn vs. raw corn-treated silage. These results indicate that supplementation of either raw or heated corn on PS at ensiling could minimize proteolysis and improve fer-
\end{abstract}

Received September 27, 2004.

Accepted April 6, 2005.

E-mail: cmyang@niu.edu.tw. mentation efficiency. Advantages from using heated vs. raw corn could extend beyond silage fermentation and include rumen microbial fermentation.

(Key words: legume silage, proteolysis, corn, fermentation)

Abbreviation key: $\mathbf{B C}=$ buffering capacity, $\mathbf{C E}=$ cellulose, $\mathbf{H E}=$ hemicellulose, $\mathbf{N P N A N}=$ nonprotein nonammonia N, PS = peanut stover, WSC = water-soluble carbohydrates.

\section{INTRODUCTION}

Good quality legume forages such as alfalfa are rather scarce in subtropical regions of the world. Peanut stover (PS) is an available source of legume for dairy cows in Taiwan. It has a chemical composition comparable to full-bloom alfalfa hay (NRC, 1989). The production of PS in Taiwan is concentrated in June when the ambient temperature is high along with frequent rain showers. Under these conditions, fresh PS deteriorates rapidly. It would be difficult to use PS for animal feeding for extended periods without proper conservation. Ensilage may be an appropriate way to conserve PS without the interruption and damage caused by rain.

Legume forages often undergo extensive proteolysis during silage fermentation, with the production of various NPN components (Ohshima and McDonald, 1978). Muck (1987) indicated that up to $70 \%$ of the $\mathrm{N}$ in alfalfa silage could be in the form of NPN. The conversion of protein N to NPN may have negative impacts on forage $\mathrm{N}$ use by ruminants. Nagel and Broderick (1992) demonstrated that large amounts of NPN reduced the efficiency of use of alfalfa silage CP by lactating dairy cows. Low efficiency of silage $\mathrm{N}$ use could result from an imbalance of silage $\mathrm{N}$ (fast rate of $\mathrm{N}$ release) and energy (slow rate of carbohydrate fermentation) availability in the rumen. High proportions ( $>70 \%$ ) of silage $\mathrm{N}$ ingested by animal would then be converted to ammonia in the rumen (Siddons et al., 1985). Excess ammonia absorbed by the animal incurs further inefficiency by consuming energy to transform it into urea before disposal into the environment.

Protein decomposition following the onset of ensiling results from plant and microbial enzymatic activity 
(McDonald et al., 1991). Ensiling at greater DM concentrations minimizes heating, and fast $\mathrm{pH}$ decline after ensiling has been shown to reduce proteolysis in alfalfa (Muck, 1987, 1988). Legumes are generally low in water-soluble carbohydrates (WSC) but high in buffering capacity (BC) (McDonald et al., 1991). These conditions can limit $\mathrm{pH}$ reduction during silage fermentation. In addition, legume stems are tubular and hollow in structure. Therefore, the mass for ensiling would be porous to air. Presence of air within the ensiling mass may enhance plant respiration and aerobic microbial activity with the production of heat. Heating during the initial stage of ensiling not only promotes proteolysis but also consumes sugars, reducing the quantity of readily fermentable carbohydrates available for subsequent anaerobic fermentation.

The PS could also be stemmy, and is expected to contain low WSC because of its maturity. In these circumstances, the ensiled PS would be prone to high $\mathrm{pH}$ and excessive heating. Furthermore, fresh PS is rather moist (>70\%). Muck (1988) indicated that forages with high moisture content required extra fermentable carbohydrates to effectively reduce $\mathrm{pH}$ during fermentation.

Corn is a practical source of NFC and has been used to supplement forages at ensiling, speeding $\mathrm{pH}$ decline during fermentation (Sibanda et al., 1997; Yang et al., 2004). In addition to providing fermentable carbohydrates, the fine particle size of corn meal may aid to decrease the porosity of silage mass, favoring anaerobic fermentation. This effect of compaction may reduce wasteful plant respiration and suppress heating. Because proteolysis is less extensive at low $\mathrm{pH}$ and temperature (McKersie, 1985; Muck, 1988), and at high DM (Muck, 1988; Muck and Dickerson, 1988), adding corn to legume at ensiling to increase both DM and fermentable carbohydrates could potentially benefit both silage fermentation and nutritive value by reduction in $\mathrm{pH}$ and NPN.

Few attempts have been made to evaluate the effect of adding corn to legume before ensiling on silage fermentation characteristics and soluble NPN. Sibanda et al. (1997) added corn at ensiling to tropical grass (star grass) containing incremental amounts of a subtropical legume (silverleaf) and observed decreased silage $\mathrm{pH}$ and volatile $\mathrm{N}$, presumably ammonia, when the silage contained high but not low amounts of legume. However, the effect on other fractions of silage $\mathrm{N}$ and the extent of proteolysis was uncertain. Furthermore, silage fermentation efficiency was apparently reduced with corn treatment, because silage acetic acid increased but not lactic acid. The decreased fermentation efficiency may compromise benefits from silage ammonia reduction.
Heat treatment of corn can increase carbohydrate availability (Theurer et al., 1999; DePeters et al., 2003). It is possible that adding heated corn vs. raw corn to legume for ensilage could ensure a more homolactic fermentation and further decrease silage soluble NPN and proteolysis by furnishing more readily fermentable carbohydrates to further reduce $\mathrm{pH}$. In addition to exerting an effect during ensilage by increasing the rate of ruminal carbohydrate fermentation, silage treated with heated corn could result in elevated propionic acid and a more effective capture of end products from protein breakdown with reduction in ammonia in the rumen (Nocek and Russell, 1988). The objective of this study was to evaluate the effect of incorporating raw or heated corn meal into PS before ensiling on silage $\mathrm{N}$ components, fermentation characteristics, and digestion by ruminal microorganisms.

\section{MATERIALS AND METHODS}

\section{Silage Preparation}

The PS was collected manually from a field soon after harvesting of peanuts and immediately ensiled alone or with $10 \%$ of raw or heated corn meal as an NFC source, on a fresh weight basis. The raw and heated $\left(170^{\circ} \mathrm{C}\right.$ air, $\left.30 \mathrm{~s}\right)$ corns were purchased from a local feed mill (Good Feed Industry Co. Ltd., Luchu, Kaohsiung, Taiwan, ROC).

The chemical composition of PS shows great similarity to full-bloom alfalfa hay (NRC, 1989). The amount of corn addition to PS at ensiling was adjusted so that the DM content of the mixture was near $30 \%$, which is considered adequate for proper silage fermentation (Muck, 1988; McDonald et al., 1991) and to increase the NFC content over that of full-bloom alfalfa hay (NRC, 1989). Based on the DM and NFC contents of the separate ingredients (Table 1), the mixture with added corn entering the silo was estimated to comprise $31.1 \% \mathrm{DM}$ and $36.1 \% \mathrm{NFC}$. The DM inclusion rate of corn was approximately $25.5 \%$. A description of the silos, the ensiling procedure, and silage sampling methods are given in a previous report (Yang et al., 2004).

\section{Laboratory Analyses}

Initial PS, corn, and silage samples were analyzed for DM by oven drying at $55^{\circ} \mathrm{C}$ for $48 \mathrm{~h}$, ether extract and $\mathrm{CP}$ (AOAC, 1990), NDF, ADF, acid detergent lignin, and acid-insoluble ash (Van Soest et al., 1991), WSC (Thomas, 1977), and BC (Playne and McDonald, 1966). Ash was determined in a muffle furnace at $550^{\circ} \mathrm{C}$ for $8 \mathrm{~h}$. The OM, hemicellulose (HE), and cellulose (CE) were estimated by differences. The NFC content was calculated by subtracting $\mathrm{CP}$, ether extract, and NDF 
Table 1. Chemical composition of fresh peanut stover, and raw and heated corn for ensilage.

\begin{tabular}{|c|c|c|c|c|}
\hline Items $^{1}$ & $\begin{array}{l}\text { Peanut } \\
\text { stover }\end{array}$ & $\begin{array}{l}\text { Raw } \\
\text { corn }\end{array}$ & $\begin{array}{l}\text { Heated } \\
\text { corn }\end{array}$ & Alfalfa $^{2}$ \\
\hline DM, \% & 25.5 & 86.5 & 88.4 & - \\
\hline $\mathrm{OM}, \%$ of $\mathrm{DM}$ & 89.7 & 98.7 & 99.4 & 91.1 \\
\hline $\mathrm{EE}, \%$ of DM & 2.4 & 3.6 & 3.6 & 2 \\
\hline $\mathrm{NDF}, \%$ of $\mathrm{DM}$ & 52.4 & 9.8 & 9.1 & 50 \\
\hline $\mathrm{ADF}, \%$ of $\mathrm{DM}$ & 39.3 & 2.9 & 2.4 & 37 \\
\hline $\mathrm{HE}, \%$ of DM & 13.1 & 6.9 & 6.7 & 13 \\
\hline $\mathrm{CE}, \%$ of $\mathrm{DM}$ & 29.4 & 0.3 & 0.9 & 28 \\
\hline $\mathrm{ADL}, \%$ of $\mathrm{DM}$ & 8.2 & 1.8 & 1.0 & 10 \\
\hline AIA, \% of DM & 2.1 & 0.8 & 0.5 & - \\
\hline NFC, $\%$ of DM & 21.5 & 75.9 & 77.5 & 24.1 \\
\hline WSC, \% of DM & 8.4 & 1.1 & 2.0 & - \\
\hline $\mathrm{BC}, \mathrm{mEq} \%$ of $\mathrm{DM}$ & 37.7 & 8.4 & 5.8 & - \\
\hline \multirow[t]{2}{*}{$\mathrm{CP}, \%$ of $\mathrm{DM}$} & 13.6 & 9.4 & 9.2 & 15 \\
\hline & \multicolumn{4}{|c|}{$-(\%$ of total $\mathrm{N})$} \\
\hline Water-soluble N & 43.1 & 18.1 & 17.8 & - \\
\hline Soluble protein $\mathrm{N}$ & 19.4 & 1.8 & 4.4 & - \\
\hline Soluble NPN & 23.7 & 16.2 & 13.3 & - \\
\hline NPNAN & 6.1 & 6.0 & 4.1 & - \\
\hline $\mathrm{NH}_{3}-\mathrm{N}$ & 0.2 & 0.1 & 0.1 & - \\
\hline Other soluble NPN & 17.4 & 10.1 & 9.1 & - \\
\hline
\end{tabular}

${ }^{1} \mathrm{EE}=$ Ether extract, $\mathrm{HE}=$ hemicellulose, $\mathrm{CE}=$ cellulose, $\mathrm{ADL}=$ acid detergent lignin, AIA = acid-insoluble ash, WSC $=$ water-soluble carbohydrates, $\mathrm{BC}=$ buffering capacity, NPNAN = nonprotein nonammonia N.

${ }^{2}$ Numbers originated from tabular values for full-bloom alfalfa hay in NRC (1989).

from OM. In addition, $\mathrm{pH}$, lactic acid, and VFA were determined on acid extracts of fresh silages using methods described previously (Yang et al., 2004), as well as for ammonia N (Weatherburn, 1967).

For soluble CP, oven-dried feeds were immersed in distilled water at $45^{\circ} \mathrm{C}$ for $1 \mathrm{~h}$ before filtration through Whatman 54 filter paper (Whatman, Clifton, NJ). The water filtrate was collected for determination of various $\mathrm{N}$ fractions. The residues on the paper were analyzed for $\mathrm{CP}$ (AOAC, 1990) and designated as water-insoluble $\mathrm{CP}$. Water-soluble CP was calculated as the difference between total CP and insoluble CP. Feed water filtrate was treated with $25 \%$ (wt/vol) TCA to precipitate protein (Muck, 1987). The TCA-insoluble protein was then dissolved in $0.2 \mathrm{~N} \mathrm{NaOH}$ and assayed for protein using the method of Lowry et al. (1951) by comparison with a BSA standard. The difference between water-soluble $\mathrm{CP}$ and TCA-insoluble protein was considered as watersoluble NPN. The deproteinized water filtrate was dried $\left(110^{\circ} \mathrm{C}, 30 \mathrm{~min}\right)$ to remove ammonia, and hydrolyzed with $6 \mathrm{~N} \mathrm{HCl}\left(110^{\circ} \mathrm{C}, 24 \mathrm{~h}\right)$ under an $\mathrm{N}_{2}$ atmosphere. The samples were then adjusted to $\mathrm{pH} 5.4$ with $6 \mathrm{~N}$ $\mathrm{NaOH}$ and assayed for amino $\mathrm{N}$ by ninhydrin using glycine as a standard (Rosen, 1957). This fraction was designated as nonprotein nonammonia N (NPNAN), presumably consisting of peptide plus amino acid. Pep- tide size of the NPNAN fraction was estimated from the ninhydrin reaction before and after $\mathrm{HCl}$ hydrolysis.

Ruminal in vitro digestibility ( $48 \mathrm{~h}$ ) was determined on silages. The incubation (triplicate) conditions and preparation of ruminal fluid, as described previously (Yang, 2002), were similar to those of Goering and Van Soest (1970), except roll glass tubes (Bellco, Vineland, $\mathrm{NJ}$ ) sealed with rubber stoppers and aluminum crimps were used as incubation vessels. Gas production was measured using graduated glass syringes. The contents of incubations at termination were also analyzed for VFA and ammonia $\mathrm{N}$ by the methods described for silages. The amounts (milligrams) of in vitro ammonia accumulated per unit (gram) of DM digested by ruminal microorganisms over the entire incubation time were used to compute synchronization indexes. The lower the index, the higher was the degree of synchrony between ruminal protein and carbohydrate fermentation.

\section{Statistical Analyses}

Data were analyzed as a completely randomized design using the GLM procedures of SAS (SAS Institute, 1998), with treatment as the main effect in the model $(\mathrm{n}=9)$. Treatment comparisons were made by orthogonal contrasts of control vs. corn-treated silages and raw vs. heated corn-treated silages. Contrasted variables were considered significant at $P<0.05$.

\section{RESULTS AND DISCUSSION}

\section{Chemical Composition of Ensiling Ingredients}

Compositions of initial PS and corns are in Table 1. Fresh PS collected in this study had chemical composition values similar to those tabulated for full-bloom alfalfa hay in NRC (1989). The OM, CP, lignin, and NFC were slightly lower for PS than for full-bloom alfalfa hay. On the contrary, ether extract, NDF, ADF, and CE were slightly higher for PS than for full-bloom alfalfa hay. Raw and heated corns were virtually identical in chemical composition but fresh PS had much lower contents of DM and NFC. Opposite trends occurred for $\mathrm{CP}$, water-soluble $\mathrm{N}$ fractions, structural carbohydrates, WSC, and BC.

\section{Silage DM and Carbohydrate Constituents}

The contents of DM, carbohydrate fractions, and ether extract in PS ensiled without and with raw or heated corn are presented in Table 2 . Treatment differences observed generally reflected compositional variations among feeds in combination with the mixing ratio before ensiling. Adding corn to PS effectively increased silage DM contents over the control silage. The DM 
Table 2. Carbohydrate constituents of peanut stover ensiled alone (control) or with raw or heated corn.

\begin{tabular}{|c|c|c|c|c|c|c|}
\hline \multirow[b]{2}{*}{ Items $^{1}$} & \multicolumn{3}{|c|}{ Treatment } & \multirow[b]{2}{*}{ SEM } & \multicolumn{2}{|c|}{ Estimated $^{2}$} \\
\hline & Control & $\begin{array}{l}\text { Raw } \\
\text { corn }\end{array}$ & $\begin{array}{l}\text { Heated } \\
\text { corn }\end{array}$ & & $\begin{array}{l}\text { Raw } \\
\text { corn }\end{array}$ & $\begin{array}{l}\text { Heated } \\
\text { corn }\end{array}$ \\
\hline $\mathrm{DM}, \%^{\mathrm{a}}$ & 22.1 & 29.0 & 28.8 & 1.3 & 31.0 & 31.2 \\
\hline $\mathrm{OM}, \%$ of DM & 87.4 & 89.6 & 89.8 & 0.5 & 91.9 & 92.0 \\
\hline $\mathrm{NDF}, \%$ of $\mathrm{DM}^{\mathrm{a}}$ & 50.2 & 42.4 & 44.6 & 0.8 & 41.6 & 41.3 \\
\hline $\mathrm{ADF}, \%$ of $\mathrm{DM}^{\mathrm{a}}$ & 44.6 & 34.0 & 35.3 & 0.7 & 30.1 & 29.8 \\
\hline $\mathrm{HE}, \%$ of $\mathrm{DM}^{\mathrm{a}}$ & 5.5 & 8.4 & 9.3 & 0.4 & 11.5 & 11.5 \\
\hline $\mathrm{CE}, \%$ of $\mathrm{DM}^{\mathrm{a}}$ & 32.2 & 23.9 & 25.1 & 0.9 & 22.0 & 22.1 \\
\hline $\mathrm{ADL}, \%$ of $\mathrm{DM}^{\mathrm{a}}$ & 9.9 & 7.5 & 7.2 & 0.4 & 6.5 & 6.3 \\
\hline $\mathrm{HE}: \mathrm{CE}^{\mathrm{a}}$ & 0.17 & 0.32 & 0.38 & 0.04 & 0.52 & 0.52 \\
\hline $\mathrm{ADF}, \%$ of $\mathrm{NDF}^{\mathrm{a}}$ & 88.9 & 75.5 & 77.4 & 1.2 & 72.4 & 72.2 \\
\hline AIA, \% of $\mathrm{DM}^{\mathrm{a}}$ & 2.4 & 1.8 & 1.6 & 0.2 & 1.8 & 1.7 \\
\hline $\mathrm{NFC}, \%$ of $\mathrm{DM}^{\mathrm{a}}$ & 20.1 & 28.8 & 26.1 & 1.0 & 35.9 & 36.6 \\
\hline WSC, \% of DM & 1.0 & 1.2 & 1.1 & 0.1 & 6.5 & 6.7 \\
\hline $\mathrm{EE}, \%$ of $\mathrm{DM}^{\mathrm{a}}$ & 3.9 & 4.4 & 5.0 & 0.2 & 2.8 & 2.8 \\
\hline
\end{tabular}

${ }^{\mathrm{a} C}$ Control vs. corn-treated silages, $P<0.05$.

${ }^{1} \mathrm{HE}=$ Hemicellulose, $\mathrm{CE}=$ cellulose, $\mathrm{ADL}=$ acid detergent lignin, AIA = acid-insoluble ash, WSC = water-soluble carbohydrates, $\mathrm{EE}=$ ether extract.

${ }^{2}$ Numbers are theoretical estimates according to the inclusion rates and chemical contents (Table 1) of the separate ingredients.

values of corn-treated silages were near the target of $30 \%$ considered adequate for proper silage fermentation (McDonald et al., 1991). Silage NDF, ADF, CE, acid detergent lignin, and acid-insoluble ash contents were diluted by corn treatment. In contrast, values for $\mathrm{HE}$, $\mathrm{NFC}$, and ether extract were higher for silages produced with corn compared with corresponding values for the untreated control. No differences between corn-treated silages were detected.

The ensiling process apparently altered carbohydrate composition of PS. The content of NDF in fresh PS was numerically higher than in the silage, whereas difference in ADF was the opposite (Tables 1 and 2). This result was reflected in the HE fraction in the silage, which reduced markedly after ensiling, and was likely used as a substrate during silage fermentation (Muck, 1988). The elevation in ADF proportion of NDF and decrease in $\mathrm{HE}$ to $\mathrm{CE}$ ratio of the silage compared with fresh PS confirm a substantial loss of HE. Fresh PS had higher contents of NFC and WSC than PS silage, as could be anticipated from saccharolytic activity during silage fermentation (McDonald et al., 1991).

Variations in composition of corn-containing silages also indicated the involvement of ensiling, more than just a general dilution or addition effect by corn treatment. Concentrations of structural carbohydrates were elevated, and nonstructural carbohydrates were reduced after ensiling in corn-treated silages when compared with the theoretical estimates based on the original contents and inclusion rates of the separate ingredients (Table 2). Therefore, except for slightly increased
Table 3. Fermentation acids and $\mathrm{pH}$ of peanut stover ensiled alone (control) or with raw or heated corn.

\begin{tabular}{|c|c|c|c|c|}
\hline \multirow[b]{2}{*}{ Item } & \multicolumn{3}{|c|}{ Treatment } & \multirow[b]{2}{*}{ SEM } \\
\hline & Control & $\begin{array}{l}\text { Raw } \\
\text { corn }\end{array}$ & $\begin{array}{l}\text { Heated } \\
\text { corn }\end{array}$ & \\
\hline & 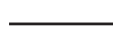 & of $\mathrm{Dl}$ & — & \\
\hline Total acid ${ }^{\mathrm{a}}$ & 6.6 & 7.2 & 7.3 & 0.1 \\
\hline Lactic acid $(\mathrm{L})^{\mathrm{a}}$ & 4.0 & 5.6 & 5.8 & 0.3 \\
\hline Acetic acid $(\mathrm{A})^{\mathrm{a}}$ & 1.6 & 1.0 & 0.8 & 0.1 \\
\hline Propionic acid ${ }^{a}$ & 0.94 & 0.62 & 0.64 & 0.07 \\
\hline $\mathrm{L}: \mathrm{A}^{\mathrm{a}}$ & 2.6 & 5.9 & 6.9 & 0.3 \\
\hline $\mathrm{pH}^{\mathrm{a}}$ & 4.70 & 4.32 & 4.22 & 0.05 \\
\hline
\end{tabular}

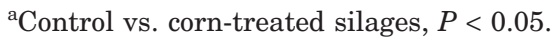

$\mathrm{NDF}$, the general trend in alterations in carbohydrate fractions due to ensiling was consistent with that in untreated forage. Again, preferential use of HE to other fibrous components was obvious in corn-treated silages but to a smaller extent compared with NFC. Losses of $\mathrm{HE}$ on ensilage were estimated to be $57.8,26.8$, and $19.1 \%$ for control, raw corn, and heated corn treatments, respectively. However, 6.94, 19.8, and $29.8 \%$ of NFC were lost for the corresponding treatments. Thus, changes following corn treatment were characterized by a shift in carbohydrate use by silage microorganisms from HE to NFC. Hydrolysis of HE and NFC both could provide sugars (hexoses and pentoses) needed for lactic acid fermentation (Muck, 1988). The extent of reduction in WSC after ensiling was even more substantial, roughly $85 \%$, but was essentially similar among treatments. These observations illustrated a preference trend on carbohydrates by silage microorganisms based on the ease of fermentability (WSC $>\mathrm{NFC}>\mathrm{HE}>\mathrm{CE}$ ). Regardless, corn-treated silages had carbohydrate compositions close to those of early bloom and midbloom alfalfa hay (NRC, 1989).

Values for ether extract were higher for silages produced with corn compared with the untreated control (Table 2), probably related to the transformation of greater amounts of fermentable carbohydrates into silage acids. The elevated silage ether extract contents for all silages over the theoretical estimates likely resulted from fermentation acids produced during ensilage (McDonald et al., 1991).

\section{Silage Fermentation Acids and $\mathrm{pH}$}

Treating PS with corn at the time of ensiling resulted in silages with greater amounts of total acids produced (Table 3). This corresponds with higher ether extract contents in silages with added corn (Table 2). Lactic acid was the predominant fermentation acid for all silages, but was higher in corn-treated silages. The inverse trend was the case for acetic and propionic acids. 
As a result, ratios of lactic acid to acetic acid were greater in silages treated with corn.

Consistent with elevated lactic acid, silage $\mathrm{pH}$ decreased in response to corn addition, with no differences between sources of corn added. The $\mathrm{pH}$ of control silage was higher than the critical level of 4.2, despite the fact that lactic acid was in excess of the minimum $(3 \%$ of DM) for good-quality silage (McDonald et al., 1991). Fresh PS (Table 1) contained WSC slightly less than adequate $(<10 \%$ of $\mathrm{DM})$, and was high in both $\mathrm{BC}(>30$ $\mathrm{mEq} \%)$ and moisture content $(>70 \%)$ over the concentrations for ideal silage preservation (McDonald et al., 1991). Because lactic acid concentration appeared adequate, high $\mathrm{pH}$ associated with $\mathrm{PS}$ silage might have been a result of high $\mathrm{BC}$ and moisture concentration. It seems that a lactic acid concentration higher than normally considered adequate might be necessary to effectively reduce the $\mathrm{pH}$ of PS silage. Adding corn increased production of lactic acid during ensilage and reduced $\mathrm{pH}$ to near 4.2. This result supports the assumption that forages with high moisture content and $\mathrm{BC}$ may require extra fermentable carbohydrates to reduce $\mathrm{pH}$ during silage fermentation (Muck, 1988).

Because corn contained much less WSC compared with NFC (Table 1), fermentable carbohydrates in corn presumably originated from the NFC fraction other than WSC. Indeed, estimated losses of NFC (discussed above) due to ensiling among treatments were lowest for control and highest for heated corn treatment. These relative changes in NFC reduction closely followed the increases in lactic acid and decreases in $\mathrm{pH}$. On the contrary, estimated losses of other sources of fermentable carbohydrates (see above), such as WSC and $\mathrm{HE}$, did not correlate to $\mathrm{pH}$ reduction.

Additional corn seemed to promote a more homolactic fermentation, as indicated by the increased lactic acid production with simultaneous decreases in volatile fatty acids (Cussen et al., 1995). As a result, the efficiency of silage fermentation, judged by greater lactic to acetic acid ratios, was improved when corn was included in silages to exceed the value of 3 considered ideal for fermentation (Cussen et al., 1995). Sibanda et al. (1997) added corn to tropical grass with high amounts of legume at ensiling and observed a decreased silage $\mathrm{pH}$. However, silage lactic acid did not increase. Instead, both acetic and butyric acids increased. Their results imply an otherwise enhanced heterolactic fermentation with low efficiency by corn addition.

Butyric acid was not detected in any of the silages, although control silage contained high moisture $(>70 \%)$ with moderate $\mathrm{pH}(>4.5)$, which would favor clostridial fermentation with the production of butyric acid (McDonald et al., 1991).

\section{Nitrogenous Constituents}

Silage CP contents were unaffected by treatment (Table 4). However, significant alternations in silage $\mathrm{N}$ components by corn supplementation were detected. As expected from $\mathrm{N}$ fractions of the original feeds (Table 1 ), silages treated with corn contained less water-soluble $\mathrm{N}$ in total $\mathrm{N}$ compared with the control. This result was reflected in both subfractions, water-soluble protein $\mathrm{N}$ and NPN. Within the NPN fraction, NPNAN (peptides plus amino acids) and ammonia $\mathrm{N}$ also reduced in corntreated silages.

The ensiling process appeared to exert different influences on various $\mathrm{N}$ components among treatments, when compared the observed with the original compositions from theoretical estimates. The CP of PS silage was numerically lower than that of fresh PS (Tables 1 and 4). Conversely, the $\mathrm{CP}$ of corn-treated silages seemed to increase after ensiling. This decrease or increase in CP after ensiling could have resulted from increased ammonia losses from proteolysis or microbial synthesis during fermentation (McDonald et al., 1991).

Water-soluble $\mathrm{N}$, as percentage of the total $\mathrm{N}$, in the PS silage was higher than in the initial forage, in agreement with previous observations with alfalfa (Albrecht and Muck, 1991). In contrast, the values decreased by 4.1 and $7.9 \%$ for raw and heated corn treatments, respectively.

The ensiling process apparently altered water-soluble $\mathrm{N}$ subfractions (i.e., protein N and NPN) in PS, but in a greater magnitude than water-soluble N. In this case, soluble-protein $\mathrm{N}$ reduced after ensiling in all silages to a similar extent of about $64 \%$. This result is most likely because of the action of proteases during silage fermentation (McDonald et al., 1991).

In contrast to soluble protein $\mathrm{N}$ (which decreased), soluble NPN of all silages increased after ensiling. Muck (1987) and Fairbairn et al. (1988) also reported increased NPN in alfalfa during silage fermentation. Muck (1987) observed that soluble NPN represented 20 to $30 \%$ of the total $\mathrm{N}$ in fresh alfalfa. After ensiling, soluble NPN may account for 40 to $85 \%$ of total N. The NPN values for fresh (23.7\%) and ensiled (39.4\%) PS in the current study are within the respective ranges. In another study by Fairbairn et al. (1988), alfalfa silage $\mathrm{N}$ was found to contain $41 \% \mathrm{NPN}$.

Plant enzymes and microbial proteolysis during ensiling result in extensive conversion of soluble proteins to NPN fractions (McDonald et al., 1991). The increase in NPN is often considered an indication of proteolysis in ensiled forage (Ohshima and McDonald, 1978). The total amount of proteolysis (changes in NPN as a percentage of total $\mathrm{N}$ between initial and ensiled PS) in this study was approximately $66 \%$. In corn-treated si- 
Table 4. Nitrogenous components of peanut stover ensiled alone (control) or with raw or heated corn.

\begin{tabular}{|c|c|c|c|c|c|c|}
\hline \multirow[b]{2}{*}{ Item $^{1}$} & \multicolumn{3}{|c|}{ Treatment } & \multirow[b]{2}{*}{ SEM } & \multicolumn{2}{|c|}{ Estimated $^{2}$} \\
\hline & Control & $\begin{array}{l}\text { Raw } \\
\text { corn }\end{array}$ & $\begin{array}{l}\text { Heated } \\
\text { corn }\end{array}$ & & $\begin{array}{l}\text { Raw } \\
\text { corn }\end{array}$ & $\begin{array}{l}\text { Heated } \\
\text { corn }\end{array}$ \\
\hline \multirow[t]{2}{*}{$\mathrm{CP}, \%$ of $\mathrm{DM}$} & 12.9 & 13.8 & 13.9 & 0.4 & 12.5 & 12.5 \\
\hline & \multicolumn{3}{|c|}{$\longrightarrow(\%$ of total $\mathrm{N})$} & & \multicolumn{2}{|c|}{$-(\%$ of total $\mathrm{N})-$} \\
\hline Water-soluble $\mathrm{N}^{\mathrm{a}}$ & 46.7 & 35.1 & 33.9 & 1.1 & 36.6 & 36.8 \\
\hline Soluble protein $\mathrm{N}^{\mathrm{a}}$ & 7.3 & 5.7 & 5.4 & 0.4 & 15.1 & 15.8 \\
\hline Soluble NPNa & 39.4 & 29.4 & 28.5 & 1.9 & 21.8 & 21.0 \\
\hline NPNAN $^{\mathrm{a}}$ & 18.2 & 10.7 & 11.5 & 1.5 & 6.1 & 6.0 \\
\hline $\mathrm{NH}_{3}-\mathrm{N}^{\mathrm{a}}$ & 12.4 & 9.8 & 9.0 & 0.5 & 0.2 & 0.2 \\
\hline Other soluble NPN & 8.8 & 8.9 & 8.0 & 0.2 & 15.6 & 15.3 \\
\hline
\end{tabular}

lages, the value decreased to around $35 \%$, almost $50 \%$ lower.

The NPN fraction in ensiled forage comprises mainly peptide $\mathrm{N}$, free amino $\mathrm{N}$, ammonia $\mathrm{N}$, amides, and amines (Ohshima and McDonald, 1978). The concentration of NPNAN (peptide plus amino acid) in PS N tripled after ensiling (Tables 1 and 4), which was direct evidence of extensive proteolysis. The reduction in protein $\mathrm{N}$ in line with the increase in NPNAN indicated protease and peptidase activity from plant enzymes (Messman et al., 1994). Because the ratio of ninhydrin reactions after and before $\mathrm{HCl}$ hydrolysis was approximately 1.2 (data not shown), it appeared that much of the residual NPNAN was mainly in the form of amino acids and small peptides. The increase in NPNAN was less than 2-fold in corn-treated silages (Table 4). Regardless, peptide size was not influenced by corn treatment.

Ammonia $\mathrm{N}$ increased nearly 70 times when PS was ensiled alone (Tables 1 and 4 ). The value (12.4\% of $\mathrm{N}$ ) is comparable with that $(11.3 \%$ of $\mathrm{N})$ in alfalfa silage investigated by Fairbairn et al. (1988) and was slightly over the acceptable concentration of $10 \%$ of $\mathrm{N}$ (Church, 1991). Similar to the trend in NPNAN, a smaller increase ( $<60$ times) in ammonia $\mathrm{N}$ was observed in silage treated with corn. In this case, ammonia $\mathrm{N}$ in both corntreated silages was within the acceptable concentration. Because no butyric acid was detected for all silages, high concentrations (near or greater than $10 \%$ of total N) of ammonia $\mathrm{N}$ were probably not a result of proteolytic, clostridial activity. Sibanda et al. (1997) also observed that adding corn at ensiling to tropical grass containing high amounts of legume resulted in silages with less volatile nitrogen, presumably ammonia. However, the effect of corn addition on the extent of silage proteolysis during ensiling for individual treatments could not be realized.
The percentage of silage NPNAN and ammonia N totaled less than the percentage of NPN (Table 4). This discrepancy may be due to the presence of unidentified $\mathrm{N}$ fractions, which other researchers have also reported (Fairbairn et al., 1988). Of the NPN in PS before ensiling, about $17.4 \%$ of $\mathrm{N}$ was unaccounted for by NPNAN and ammonia-N. Fairbairn et al. (1988) also observed large amounts (15.9\% of N) of unaccounted NPN in alfalfa at ensiling. This fraction dwindled in the ensilage or as the ensiling process proceeded. In the present study, the unaccounted NPN in PS was also greatly reduced after ensiling. The remainder of the NPN was not identified in this study, but probably comprised amines, amides, or other compounds (McDonald et al., 1991). The proportions of unaccounted NPN in corntreated silages appeared similar and were lower than the pre-ensiling values (Table 4).

The extent of increases in NPN, NPNAN, and ammonia-N during ensiling was smaller for corn-treated silages compared with the control, implying that both protein decomposition and deamination might have been restricted during ensiling. It appears that the anticipated lower contents of soluble $\mathrm{N}$ fractions in corntreated silages were more than merely the dilution effect by corn treatment. The conversion of protein $\mathrm{N}$ to NPN is associated primarily with plant enzyme activity whereas changes with the NPN fraction are caused chiefly by microbial degradation of peptides and amino acids (Ohshima and McDonald, 1978). Thus, both plant enzyme activity and microbial action might have been modulated by the presence of corn.

Earlier studies indicated that silage protein hydrolysis is reduced at high DM (Muck, 1988; Muck and Dickerson, 1988) and low temperatures (McKersie, 1985; Muck, 1988), by decreasing plant enzyme activities and plant respiration rate (McDonald et al., 1991). Low $\mathrm{pH}$ also inactivates plant proteolytic enzymes accompanied 
by reduction in proteolysis (McKersie, 1985; Muck, 1988). In the present study, the initial silage DM was raised by corn addition from 22 to the $30 \%$ considered adequate for proper silage fermentation (McDonald et al., 1991). The altered profile of fermentation acids by corn treatment towards a homofermentative pathway with the resultant low $\mathrm{pH}$ is indicative of modified microbial activity. Although silage temperatures were not monitored, added corn meal would be expected to minimize the porosity of silage by making the mass more compacted and thus reduce heating from plant respiration. Overall, modifications in $\mathrm{DM}, \mathrm{pH}$, and temperature are the most likely ways whereby added corn reduced proteolysis via plant and microbial activity.

Other sources of fermentable carbohydrates have been implicated with proteolysis reduction. In the study by Muck (1987), adding glucose (contained no CP) at ensiling to alfalfa tended to reduce the amount of proteolysis. Davis et al. (1998) likewise reported a lower ammonia $\mathrm{N}$ proportion in total $\mathrm{N}$ in line with higher residual ribulose-1,5-bisphosphate carboxylase contents in silages produced from herbage with a high concentration of WSC. However, the high WSC herbage also contained less total N. Nevertheless, these earlier results illustrate the efficacy of extra fermentable carbohydrates on proteolysis reduction. The effect of additional NFC from corn on reduction in proteolysis in the current study was in agreement with their observations. Whether the reduction in proteolysis was attributable to PS, corn, or both could not be discriminated. In addition, corn contributed about 19\% of total silage $\mathrm{N}$. It is uncertain if the intrinsic nature of corn $\mathrm{N}$ (Table 1) would have interacted with the effect on proteolysis.

\section{In Vitro Fermentation by Ruminal Microorganisms}

In vitro (48 h) DM disappearance by mixed ruminal microorganism was higher for substrate silages ensiled with corn than that of control, but did not differ between types of corn present in silages (Table 5). Such results are consistent with greater NFC and smaller NDF contents in corn-treated silages compared with the untreated control (Table 2). Gas production, which reflects digestibility by ruminal microorganisms (DePeters et al., 2003), was also greater for incubations conducted with silages treated with corn.

Total VFA, acetic, propionic, butyric, and valeric acid concentrations were higher for corn-treated silages compared with control silage. The concentrations of these variables were lower for raw than for heated corntreated silages, except for butyric and valeric acids. There were no differences in the ratio of acetic to propionic acid among treatments. Heat treatment increases the susceptibility of carbohydrates in corn to ruminal
Table 5. In vitro rumen fermentation $(48 \mathrm{~h})$ of peanut stover ensiled alone (control) or with raw or heated corn.

\begin{tabular}{|c|c|c|c|c|}
\hline \multirow[b]{2}{*}{ Item $^{1}$} & \multicolumn{3}{|c|}{ Treatment } & \multirow[b]{2}{*}{ SEM } \\
\hline & Control & $\begin{array}{l}\text { Raw } \\
\text { corn }\end{array}$ & $\begin{array}{l}\text { Heated } \\
\text { corn }\end{array}$ & \\
\hline DM disappearance, $\%^{\mathrm{a}}$ & 43.5 & 47.4 & 49.1 & 1.1 \\
\hline $\begin{array}{l}\text { Gas production, } \mathrm{mL} / \mathrm{g} \text { of } \mathrm{DM}^{\mathrm{a}} \\
\text { VFA, } M M\end{array}$ & 137 & 150 & 153 & 2 \\
\hline Total & 117.5 & 134.2 & 143.8 & 1.9 \\
\hline Acetic acid $(\mathrm{A})^{\mathrm{a}, \mathrm{b}}$ & 70.9 & 81.3 & 86.2 & 1.3 \\
\hline Propionic acid $(\mathrm{P})^{\mathrm{a}, \mathrm{b}}$ & 31.4 & 37.5 & 40.1 & 0.3 \\
\hline Butyric acid $^{\mathrm{a}}$ & 9.3 & 10.5 & 11.5 & 0.2 \\
\hline Valeric acid $^{\mathrm{a}}$ & 1.9 & 1.9 & 2.5 & 0.2 \\
\hline BCVFA $^{\mathrm{a}}$ & 4.4 & 3.4 & 3.4 & 0.2 \\
\hline A:P & 2.28 & 2.16 & 2.15 & 0.04 \\
\hline $\mathrm{pH}^{\mathrm{a}}$ & 6.56 & 6.42 & 6.38 & 0.03 \\
\hline $\mathrm{NH}_{3}, \mathrm{~m} M^{\mathrm{a}}$ & 16.2 & 14.7 & 13.9 & 0.3 \\
\hline Synchronization index $\mathrm{x}^{\mathrm{a}, \mathrm{b}}$ & 47.5 & 39.4 & 34.4 & 1.2 \\
\hline
\end{tabular}

${ }^{\mathrm{a} C}$ Control vs. corn-treated silages, $P<0.05$.

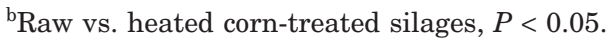

${ }^{1} \mathrm{BCVFA}=$ Branched-chain volatile fatty acids (isobutyric plus isovaleric acids); Synchronization index = milligrams of $\mathrm{NH}_{3}$ accumulated per gram of DM disappeared.

fermentation (Theurer et al., 1999; DePeters et al., 2003). Increased ruminal availability of carbohydrate would increase VFA production from heated corn compared with raw corn.

The concentrations of branched-chain VFA were lower for silages ensiled with corn. These acids arise mainly from microbial degradation of true protein (Miura et al., 1980). Greater branched-chain VFA concentrations from incubations with control silage could be directly related to higher contents of soluble protein $\mathrm{N}$ and NPNAN (Table 4). Both ammonia $\mathrm{N}$ and $\mathrm{pH}$ were reduced in incubations with corn-treated silages. The lowered $\mathrm{pH}$ reflected higher total VFA concentrations. Higher ammonia $\mathrm{N}$ together with branched-chain VFA for untreated silage is indicative of increased deamination or inadequate carbohydrate availability. Indeed, the synchronization index, expressed as the amounts (milligrams) of ammonia accumulation per unit (gram) of DM digested, was lower for corn-treated silages than for control silage, suggesting that protein and carbohydrate fermentation were better matched for corntreated silages. Dietary inclusion of fermentable carbohydrates often minimizes losses of dietary $\mathrm{N}$ and reduces ammonia in the rumen (Nocek and Russell, 1988). The index was lower for heated vs. raw corn-treated silage, which could have reflected greater carbohydrate availability from heated corn.

\section{CONCLUSIONS}

Addition of corn to PS to adjust DM and NFC contents at ensiling reduced proteolysis, enhanced fermentation 
efficiency, and increased in vitro ruminal digestibility. Modifications in DM, pH, and perhaps temperature are the most likely ways by which added corn exerted effect on proteolysis reduction. Although sometimes subtle, there was evidence of additional benefits from using heated corn vs. raw corn. More NFC in the heated corn treatment was apparently used during silage fermentation, resulting a slightly greater silage lactic acid production with lower $\mathrm{pH}$ and a smaller increase in soluble NPN. In addition, ruminal microorganisms yielded more VFA from silage with heated corn, and there was less ammonia accumulated per unit of DM digested.

\section{ACKNOWLEDGMENTS}

This study was supported by National Science Council (NSC 92-2313-B-197-008), Taiwan, Republic of China.

\section{REFERENCES}

Albrecht, K. A., and R. E. Muck. 1991. Proteolysis in forage legumes that vary in tannin concentration. Crop Sci. 31:464-469.

AOAC. 1990. Official Methods of Analysis. Vol. I. 15th ed. Association of Official Analytical Chemists, Arlington, VA.

Church, D. C. 1991. Livestock Feeds and Feeding. 3rd ed. Prentice Hall, Inc., Englewood, NJ.

Cussen, R. R., R. J. Merry, A. P. Williams, and J. K. S. Tweed. 1995. The effect of additives on the ensilage of forage of differing perennial ryegrass and white clover content. Grass Forage Sci. 50:249-258.

Davis, D. R., R. J. Merry, A. P. Williams, E. L. Bakewell, D. K. Leemans, and J. K. S. Tweed. 1998. Proteolysis during ensilage of forages varying in soluble sugar content. J. Dairy Sci. 81:444-453.

DePeters, E. J., G. Getachew, J. G. Fadel, R. A. Zinn, S. J. Taylor, J. W. Pareas, R. G. Hinders, and M. S. Aseltine. 2003. In vitro gas production as a method to compare fermentation characteristics of steam-flaked corn. Anim. Feed Sci. Technol. 105:109-122.

Fairbairn, R., I. Alli, and B. E. Baker. 1988. Proteolysis associated with the ensiling of chopped alfalfa. J. Dairy Sci. 71:152-158.

Goering, H. K., and P. J. Van Soest. 1970. Forage Fiber Analyses (Apparatus, Reagents, Procedures and Some Applications). Agric. Handbook No. 379. ARS-USDA, Washington, DC.

Lowry, O. H., N. J. Rosebrough, A. L. Farr, and R. J. Randall. 1951. Protein measurement with the Folin phenol reagent. J. Biol. Chem. 193:265-275.

McDonald, P., A. R. Henderson, and S. J. E. Heron. 1991. The Biochemistry of Silage. 2nd ed. Chalcombe Publ., Bucks., England.

McKersie, B. D. 1985. Effect of $\mathrm{pH}$ on proteolysis in ensiled legume forage. Agron. J. 77:81-86.
Messman, M. A., W. P. Weiss, and M. E. Koch. 1994. Changes in total and individual proteins during drying, ensiling, and ruminal fermentation of forages. J. Dairy Sci. 77:492-500.

Miura, H., M. Horiguchi, and T. Matsumoto. 1980. Nutritional interdependence among rumen bacteria, Bacteroides amylphilius, Megasphaera elsdenii, and Ruminococcus albus. Appl. Environ. Microbiol. 40:294-300.

Muck, R. E. 1987. Dry matter level effects on alfalfa silage quality: I. Nitrogen transformations. Trans. ASAE 30:7-14.

Muck, R. E. 1988. Factors influencing silage quality and their implications for management. J. Dairy Sci. 71:2992-3002.

Muck, R. E., and J. T. Dickerson. 1988. Storage temperature effects on proteolysis in alfalfa silage. Trans. ASAE 31:1005-1009.

Nagel, S. A., and G. A. Broderick. 1992. Effect of formic acid or formaldehyde treatment of alfalfa silage on nutrient utilization by dairy cows. J. Dairy Sci. 75:140-154.

Nocek, J. E., and J. B. Russell. 1988. Protein and energy as an integrated system. Relationship of ruminal protein and carbohydrate availability to microbial synthesis and milk production. J. Dairy Sci. 71:2070-2107.

NRC. 1989. Nutrient Requirements of Dairy Cattle. 6th rev. ed. National Academy Press, Washington, DC.

Ohshima, M., and P. McDonald. 1978. A review of the changes in nitrogenous compounds of herbage during ensilage. J. Sci. Food Agric. 29:497-505.

Playne, M. J., and P. McDonald. 1966. The buffering constituents of herbage and of silage. J. Sci. Food Agric. 17:264-268.

Rosen, H. 1957. A modified ninhydrin colorimetric analysis for amino acids. Arch. Biochem. Biophys. 67:10-15.

SAS Institute. 1998. SAS User's Guide. Statistics. Version 7 ed. 1998. SAS Institute. Inc., Cary, NC.

Sibanda, S. R., M. Jingura, and J. H. Topps. 1997. The effect of level of inclusion of the legume Desmodium uncinatum and the use of molasses or ground maize as additives on the chemical composition of grass- and maize-legume silages. Anim Feed Sci. Technol. 68:295-305.

Siddons, R. C., J. V. Nolan, D. E. Beever, and J. C. MacRae. 1985. Nitrogen digestion and metabolism in sheep consuming diets containing different forms and levels of N. Br. J. Nutr. 54:175-187.

Theurer, C. B., J. T. Huber, A. Delgado-Elorduy, and R. Wanderley. 1999. Invited Review: Summary of steam-flaking corn or sorghum grain for lactating dairy cows. J. Dairy Sci. 82:1950-1959.

Thomas, T. A. 1977. An automated procedure for the determination of soluble carbohydrates in herbage. J. Sci. Food Agric. 28:639-642.

Van Soest, P. J., J. B. Robertson, and B. A. Lewis. 1991. Methods for dietary fiber, neutral detergent fiber, and nonstarch polysaccharides in relation to animal nutrition. J. Dairy Sci. 74:35833597.

Weatherburn, M. W. 1967. Phenol-hypochlorite reaction for determinations of ammonia. Anal. Chem. 39:971-974.

Yang, C.-M. J. 2002. Response of forage fiber degradation by ruminal microorganisms to branched-chain volatile fatty acids, amino acids, and dipeptides. J. Dairy Sci. 85:1183-1190.

Yang, C.-M. J., S.-C. Huang, T. Chang, Y.-H. Cheng, and C.-T. Chang. 2004. Fermentation acids, aerobic fungal growth, and intake of napiergrass ensiled with nonfiber carbohydrates. J. Dairy Sci. 87:630-636. 